\title{
Microbial biotransformation of beclomethasone dipropionate by Aspergillus niger
}

\author{
Saeed Ahmad ${ }^{1, *}$, Farhan Hameed Khaliq ${ }^{1}$, Asadullah Madni', Muhammad Nabeel Shahid ${ }^{2}$, \\ Irfan Pervaiz ${ }^{1}$
}

${ }^{1}$ Faculty of Pharmacy and Alternative Medicine, The Islamia University of Bahawalpur, Bahawalpur, Pakistan, ${ }^{2}$ Department of Pharmaceutical Sciences, University Campus, Superior Group of Colleges, Lahore, Pakistan

\begin{abstract}
In the present research, the steroidal anti-asthmatic drug beclomethasone dipropionate was subjected to microbial biotransformation by Aspergillus niger. Beclomethasone dipropionate was transformed into various metabolites first time from microbial transformation. New drug metabolites produced can act as new potential drug molecules and can replace the old drugs in terms of safety, efficacy, and least resistance. They were purified by preparative thin layer chromatography technique, and their structures were elucidated using modern spectroscopic techniques, such as ${ }^{13} \mathrm{C} N M R,{ }^{1} \mathrm{H} \mathrm{NMR}, \mathrm{HMQC}$, HMQC, COSY, and NOESY, and mass spectrometry, such as EI-MS. Four metabolites were purified: (i) beclomethasone 17-monopropionate, (ii) beclomethasone 21-monopropionate, (iii) beclomethasone, and (iv) 9beta,11beta-epoxy-17,21-dihydroxy-16beta-methylpregna-1,4-diene-3,20-dione 21-propionate.
\end{abstract}

Uniterms: Anti-asthmatics. Aspergillus niger/use in biotransformation. Beclomethasone dipropionate/ microbial biotransformation. Steroids/microbial transformation. Biotransformation.

Na pesquisa presente o fármaco esteróide antiasmático dipropionato de beclometasona foi submetido à biotransformação microbiana pelo Aspergillus niger. O dipropionato de beclometasona foi transformado, pela primeira vez, em metabólitos variados por biotransformação microbiana. Novos metabólitos do fármaco produzidos podem agir como novas moléculas potenciais e podem substituir os fármacos antigos em questão de segurança, eficácia e mínima resistência. Eles foram purificados por cromatografia em camada delgada preparativa e as suas estruturas foram elucidadas usando técnicas espectroscópicas modernas, como ${ }^{13} \mathrm{C}$ NMR, ${ }^{1} \mathrm{H}$ NMR; HMQC; HMQC; COSY, NOESY e espectrometria de massas, por exemplo, EI-MS. Purificaram-se quatro metabólitos, denominados (i) 17-monopropionato de beclometasona; (ii) 21-monopropionato de beclometasona: (iii) beclometasona e (iv) 21-propionato de 9beta,11beta-epoxi-17,21-diidroxi-16beta-metilpregna-1,4-dieno-3,20-diona.

Unitermos: Antismáticos. Aspergillus niger/uso em biotransformação. Dipropionato de beclomentasona/ biotransformação microbiana. Esteróide/biotransformação microbiana. Biotransformação.

\section{INTRODUCTION}

Development of efficient, environmental friendly and cost-effective routes to synthesize fine chemicals is the need of the day. Biotransformation had been an exciting area of research for decades, and enzymes from various sources, that is, microorganisms, animal, and plant cells, have been employed for carrying out

\footnotetext{
*Correspondence: Saeed Ahmad. Department of Pharmacy, Faculty of Pharmacy and Alternative Medicine. The Islamia University of Bahawalpur, Bahawalpur, 63100, Pakistan. E-mail: rsahmed_iub@yahoo.com
}

reactions at chemically inaccessible positions of organic compounds (Zafar et al., 2012). Microbial transformation of steroids has been extensively investigated (Donova, Egorova, 2012), and various hydroxylated derivatives have been produced on large scale (Abourashed, Clark, Hufford, 1999). Microbial transformation of steroids has been extensively employed for the synthesis of steroidal drugs, both at laboratory and industrial levels (Choudhary et al., 2012; Choudhary et al., 2011; Choudhary et al., 2010; Al-Aboudi et al., 2009; Choudhary et al., 2009; Choudhary et al., 2007; Devkota et al., 2007). In modern drug discovery process, generation of libraries 
of bioactive compounds with diverse structures plays an important role (Tong, Dong, 2009). Aspergillus niger is classified under Aspergillus subgenus Circumdati, segment Nigri had an ability to convert the steroidal compounds into various structural derivatives, that is, methyl cholate and progesterone was converted into various metabolites (Al-Aboudi et al., 2009; Fouad et al., 2009). Beclomethasone dipropionate (1) is a drug having steroid nucleus categorized under corticosteroids (Navaratnam et al., 2009). It is prescribed by physicians for the remedy of bronchial asthma in individuals needing continuous management (Navaratnam et al., 2009), seasonal and perennial rhinitis (Chervinsky, 1996), and inhibition of reoccurrence of nasal polyps. It is used as nasal inhalation (Kanazawa et al., 2003), orally and topically (Fascì et al., 2012). Glucocorticosteroids have strong anti-inflammatory activities (Aubier et al., 2006). This drug (BDP) was a significant substance in the pharmaceutical industry as an anti-inflammatory agent (Fascì et al., 2012).

\section{MATERIALS AND METHODS}

\section{General}

Beclomethasone dipropionate (1) was purchased from Beijing Mesochem Technology Co. Ltd., China. Thin layer chromatography was carried out on precoated plates (Silica gel, Merck, PF254). Column chromatography (CC) was performed using silica gel (E. Merck, Germany). ${ }^{1} \mathrm{H}$ and ${ }^{13} \mathrm{C}$-NMR spectra were recorded in $\mathrm{CDCl}_{3}$ on Bruker Avance-NMR spectrometers. The chemical shifts $(\delta$ values) are presented in ppm, and the coupling constants (J values) are in Hertz. JEOL (Japan) JMS-600H mass spectrometer was used for recording EI-MS in $\mathrm{m} / \mathrm{z}$.

\section{Microbial Culture}

Aspergillus niger FCBP-764 was purchased from First Fungal Culture Bank of Pakistan (FCBP) grown on Saboraud dextrose agar (SDA) England. The culture medium for $A$. niger was prepared by dissolving glucose $(40 \mathrm{~g})$, yeast extract $(20 \mathrm{~g})$, peptone $(20 \mathrm{~g}), \mathrm{NaCl}(20 \mathrm{~g})$, $\mathrm{KH}_{2} \mathrm{PO}_{4}(20 \mathrm{~g})$, and glycerol $(20 \mathrm{~mL})$ in distilled water (4.0 L).

\section{Fermentation of beclomethasone dipropionate (1) and purification of metabolites}

In the experiment, we employed 40 Erlenmeyer flasks $(250 \mathrm{~mL})$ for the distribution of $4000 \mathrm{~mL}$ media in a way such that every flask comprises $100 \mathrm{~mL}$ media. Stage II fermentation procedure was used entirely for microbial transformation studies (Sepuri, Maravajhala, 2009). Liquid cultures were made in stage I by inoculating the spores of fungi from the mycelia on the Saboraud Dextrose Agar slants into the three Erlenmeyer flasks $(250 \mathrm{~mL})$, which comprises $100 \mathrm{~mL}$ of autoclaved medium. The cotton plugged flasks were then placed on rotary shaker at $114 \mathrm{rpm}$ for fungal growth for 6 to 9 days. Stage II cultures were organized by shifting small quantities of the stage I mycelia into 40 conical flasks each comprising $100 \mathrm{~mL}$ sterilized medium for three days in cotton plugged flasks on rotary shaker. After observing good growth on the third day, substrate $1 \mathrm{~g}$ beclomethasone dipropionate was dissolved in $20 \mathrm{~mL}$ chloroform and was equally distributed among all the flasks such that $25 \mathrm{mg}$ or $0.5 \mathrm{~mL}$ per flask), which were then placed on rotary shaker at $25-30{ }^{\circ} \mathrm{C}$ for more than 12 days. After accomplishment of fermentation, the fungal mass was separated, and filtrate was extracted with $n$-butanol.

The extract (organic phase) was desiccated over anhydrous $\mathrm{Na}_{2} \mathrm{SO}_{4}$, evaporated under vacuum pressure in rotary evaporator to obtain brown gummy crude extract, which was put to analysis through various chromatographic techniques.

Slurry of this crude extract was prepared in a petri dish. A wide width column was made and packed with silica gel and solvent chloroform. Slurry was loaded on to the column while carefully maintaining its surface and cotton was placed onto the slurry for comforting its surface stability throughout the procedure. At this time, slurry was eluted with gradient methanol/chloroform solvent system starting with $200 \mathrm{~mL}$ of chloroform and then $2.5 \%, 5 \%, 7.5 \%, 10 \%, 15 \%, 20 \%$, and $25 \%$ methanol $/$ chloroform $(200 \mathrm{~mL})$. Fractions obtained were desiccated in vacuum hood, and these were subjected to thin layer chromatography. Fractions showing the same metabolites on thin layer chromatography were compiled for future processes. Four fractions were achieved from the main column after compilation. Furthermore, these 4 fractions were engaged in preparative thin layer chromatography for further purification.

Fractions 1, 2, 3, and 4 were run on preparative TLC for purification because of its low quantity. All the pure samples were subjected to NMR investigations for structure elucidation.

\section{RESULTS}

Fermentation of beclomethasone dipropionate with Aspergillus niger for 12 days produced four compounds 
(2-5). The structure of identified biotransformation products of beclomethasone dipropionate (1) by Aspergillus niger are given in Figure 1.

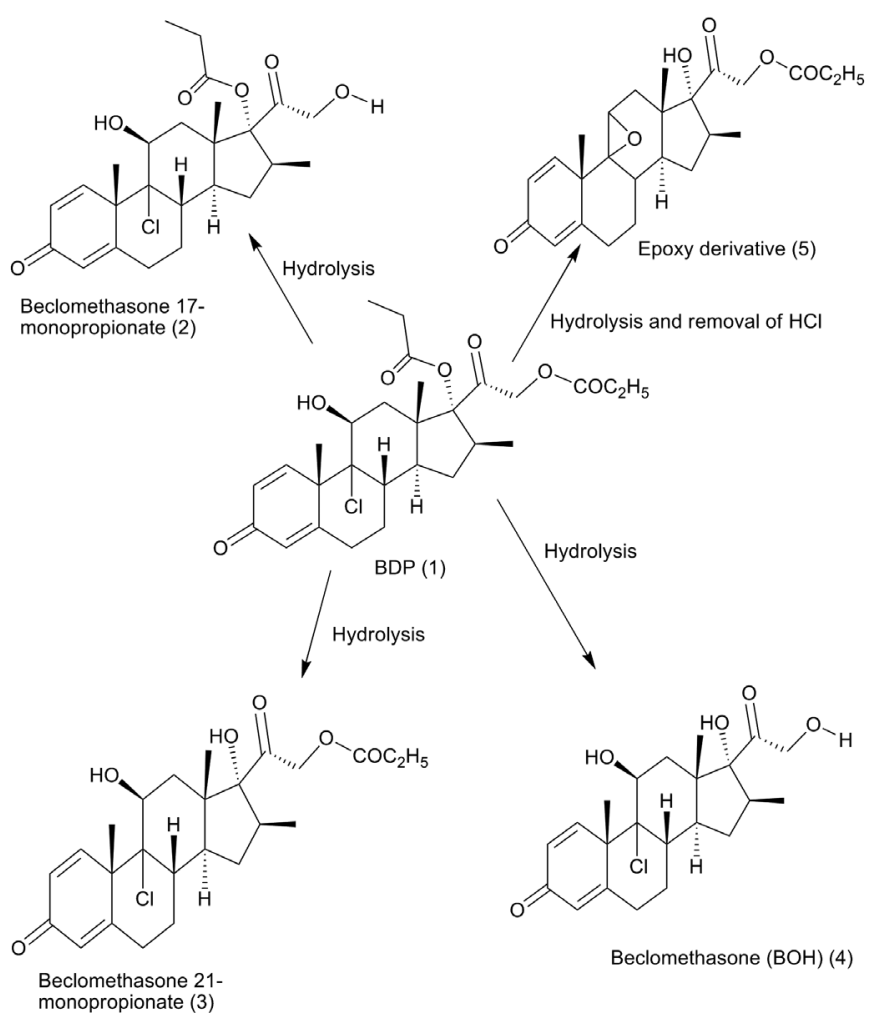

FIGURE 1 - Products resulting from the biotransformation of beclomethasone dipropionate (1) by Aspergillus niger.

\section{Beclomethasone 17-monopropionate (2)}

Colorless amorphous solid. Mol. formula: $\mathrm{C}_{25} \mathrm{H}_{33} \mathrm{ClO}_{6}$, Mol. Wt. $464.5 \mathrm{~g} / \mathrm{mol}$, HREI-MS m/z (mol. formula):465.1 $\left(\mathrm{C}_{25} \mathrm{H}_{33} \mathrm{ClO}_{6}\right),{ }^{1} \mathrm{H}-\left(400 \mathrm{MHz}, \mathrm{CDCl}_{3}\right)$ : Table I and ${ }^{13} \mathrm{C}$-NMR $\left(100 \mathrm{MHz}, \mathrm{CDCl}_{3}\right)$ : Table II.

\section{Beclomethasone 21-monopropionate (3)}

Colorless amorphous solid. Mol.formula: $\mathrm{C}_{25} \mathrm{H}_{33} \mathrm{ClO}_{6}$, Mol. Wt. 464.5g/mol, HREI-MS m/z (mol. formula): $464.9\left(\mathrm{C}_{25} \mathrm{H}_{33} \mathrm{ClO}_{6}\right),{ }^{1} \mathrm{H}-\left(400 \mathrm{MHz}, \mathrm{CDCl}_{3}\right)$ : Table I and ${ }^{13} \mathrm{C}-\mathrm{NMR}\left(100 \mathrm{MHz}, \mathrm{CDCl}_{3}\right)$ : Table II.

\section{Beclomethasone $(\mathrm{BOH})(4)$}

Colorless amorphous solid .Mol. formula: $\mathrm{C}_{22} \mathrm{H}_{29} \mathrm{ClO}_{5}$, Mol. Wt: $409.3 \mathrm{~g} / \mathrm{mol}$, HREI-MS m/z (mol. formula):409.1 $\left(\mathrm{C}_{22} \mathrm{H}_{29} \mathrm{ClO}_{5}\right) .{ }^{1} \mathrm{H}-\left(400 \mathrm{MHz}, \mathrm{CDCl}_{3}\right)$ : Table I and ${ }^{13} \mathrm{C}-\mathrm{NMR}\left(100 \mathrm{MHz}, \mathrm{CDCl}_{3}\right)$ : Table II.

\section{9 beta, 11beta-epoxy-17, 21-dihydroxy-16 beta-methylpregna-1,4-diene-3,20-dione 21-propionate (5)}

Compound (5) was purified on preparative TLC as a colorless solid. Mol. formula: $\mathrm{C}_{25} \mathrm{H}_{32} \mathrm{O}_{6}$, Mol. Wt. $431 \mathrm{~g} / \mathrm{mol}$, HREI-MS m/z (mol. formula): 429.5 $\left(\mathrm{C}_{25} \mathrm{H}_{32} \mathrm{O}_{6}\right),{ }^{1} \mathrm{H}-\left(400 \mathrm{MHz}, \mathrm{CDCl}_{3}\right)$ : Table I and ${ }^{13} \mathrm{C}-\mathrm{NMR}$ (100 MHz, $\left.\mathrm{CDCl}_{3}\right)$ : Table II.

Compound (2) had an elemental composition $\mathrm{C}_{25} \mathrm{H}_{33} \mathrm{ClO}_{6}$, deduced through HREI-MS (M+=m/z 465.1) and molecular weight is $464.5 \mathrm{~g} / \mathrm{mol}$. The compound showed fluorescence beneath UV light. This suggested that the compound has unsaturated carbonyl system. The ${ }^{13} \mathrm{C}$ - and ${ }^{1} \mathrm{H}-\mathrm{NMR}$ spectra showed the presence of the double bond between $\mathrm{C}-1 / \mathrm{C}-2$ and $\mathrm{C}-4 / \mathrm{C}-5$. The ${ }^{1} \mathrm{H}-$ and ${ }^{13} \mathrm{C}$-NMR data for metabolite (2) is given in Tables I and II, respectively. The ${ }^{13} \mathrm{C}-\mathrm{NMR}$ spectrum $\left(100 \mathrm{MHz}, \mathrm{CDCl}_{3}\right)$ (including BB, dept 90, and dept 135) of (2) showed the resonances for 4 methyl, 6 methylene, 7 methine, and 8 quaternary carbons. $17 \alpha$ propionate $\mathrm{CH}_{3}$ and $17 \alpha$ propionate $\mathrm{CH}_{2}$ group present at position 17 .

Mass spectra indicated that the mass of this compound is $465.1 \mathrm{Da}$, which is 55.94 mass units less than the substrate (521.04) and also showed the removal of $\mathrm{COC}_{2} \mathrm{H}_{4}$ (56 mass units). The net 56 mass units are less than the substrate. So metabolite (2) was thus identified as beclomethasone 17-monopropionate.

Compound (3) had an elemental composition $\mathrm{C}_{25} \mathrm{H}_{33} \mathrm{ClO}_{6}$, deduced through HREI-MS (M+=m/z 464.9), and molecular weight is $464.5 \mathrm{~g} / \mathrm{mol}$. The compound showed fluorescence beneath the UV light. This suggested that the compound has unsaturated carbonyl system. The ${ }^{13} \mathrm{C}$ - and ${ }^{1} \mathrm{H}-\mathrm{NMR}$ spectra showed the presence of the double bond between $\mathrm{C}-1 / \mathrm{C}-2$ and $\mathrm{C}-4 / \mathrm{C}-5$. The ${ }^{1} \mathrm{H}-$ and ${ }^{13} \mathrm{C}$-NMR data for metabolite (3) is given in Tables I and II, respectively. The ${ }^{13} \mathrm{C}-\mathrm{NMR}$ spectrum $\left(100 \mathrm{MHz}, \mathrm{CDCl}_{3}\right)$ (including BB, dept 90, and dept135) of (3) showed the resonances for 4 methyl, 6 methylene, 7 methine, and eight quaternary carbons and presence of 21 propionate $\mathrm{CH}_{3}$ with 21 propionate $\mathrm{CH}_{2}$ at position 21 .

Mass spectra indicated that the mass of this compound is $464.9 \mathrm{Da}$, which is 56.1 mass units less than the substrate (521.04) and also showed the removal of $\mathrm{COC}_{2} \mathrm{H}_{4}$ (56 mass units). The net 56 mass units are less than the substrate. So metabolite (3) was thus identified as beclomethasone 21-monopropionate.

Compound (4) had an elemental composition $\mathrm{C}_{22} \mathrm{H}_{29} \mathrm{ClO}_{5}$, deduced through HREI-MS (M+=m/z 409.1), and molecular weight is $408.5 \mathrm{~g} / \mathrm{mol}$. The compound showed fluorescence beneath the UV light. This suggested 
TABLE I - 'H- (400 MHz, CDCl3) Chemical shift assignments of all metabolites produced $(2,3,4,5)$

\begin{tabular}{|c|c|c|c|c|}
\hline Carbon no. & $\begin{array}{c}\text { Compound (2) } \\
\delta_{\mathrm{H}}(\mathrm{J}=\mathrm{Hz})\end{array}$ & $\begin{array}{c}\text { Compound (3) } \\
\delta_{\mathrm{H}}(\mathrm{J}=\mathrm{Hz}) \\
\end{array}$ & $\begin{array}{c}\text { Compound (4) } \\
\delta_{\mathrm{H}}(\mathrm{J}=\mathrm{Hz})\end{array}$ & $\begin{array}{c}\text { Compound (5) } \\
\delta_{\mathrm{H}}(\mathrm{J}=\mathrm{Hz})\end{array}$ \\
\hline 1 & $7.17(\mathrm{~d} 10.1)$ & $7.25(\mathrm{~d} 10.3)$ & $7.31(\mathrm{~d} 10.0)$ & $6.67(\mathrm{~d} 10.2)$ \\
\hline 2 & $6.31(\mathrm{dd} 10.1,1.8)$ & $6.26(\mathrm{dd} 10.3,2.2)$ & $6.24(\mathrm{dd} 10.0,1.8)$ & $6.23(\mathrm{dd} 10.2,1.8$ \\
\hline 3 & ------'-------- & ---------------- & ---------------- & --------------- \\
\hline 4 & $6.07(\mathrm{~s})$ & $6.09(\mathrm{~s})$ & $6.01(\mathrm{~s})$ & 6.18 (bs) \\
\hline 5 & & --- & ---- & --- \\
\hline 6 & $2.02, \mathrm{~m} ; 1.92, \mathrm{~m}$ & $2.03, \mathrm{~m} ; 1.94, \mathrm{~m}$ & $2.02, \mathrm{~m} ; 1.92, \mathrm{~m}$ & $2.03, \mathrm{dd} ; 1.90, \mathrm{td}$ \\
\hline 7 & $1.43, \mathrm{~m} ; 1.18, \mathrm{~m}$ & $1.43, \mathrm{~m} ; 1.18, \mathrm{~m}$ & $1.41, \mathrm{~m} ; 1.16, \mathrm{~m}$ & $1.40, \mathrm{~m} ; 1.19, \mathrm{~m}$ \\
\hline 8 & $1.73, \mathrm{~m}$ & $1.73, \mathrm{~m}$ & $1.71, \mathrm{~m}$ & $1.74, \mathrm{~m}$ \\
\hline 9 & & & & \\
\hline 10 & ---------------- & ------------------- & ------------- & ------------------- \\
\hline 11 & $3.48(\mathrm{~s})$ & $3.48(\mathrm{~s})$ & $3.46(\mathrm{~s})$ & $3.28(\mathrm{~s})$ \\
\hline 12 & $1.65, \mathrm{~m} ; 1.40, \mathrm{~m}$ & $1.65, \mathrm{~m} ; 1.40 \mathrm{~m}$ & $1.63, \mathrm{~m} ; 1.38 \mathrm{~m}$ & $1.64, \mathrm{~m} ; 1.39 \mathrm{~m}$ \\
\hline 13 & ----------------' & ---------------- & ---------------- & ----------------- \\
\hline 14 & $1.41, \mathrm{~m}$ & $1.41, \mathrm{~m}$ & $1.39, \mathrm{~m}$ & $1.38, \mathrm{~m}$ \\
\hline 15 & $2.14, \mathrm{~m} ; 1.86, \mathrm{~m}$ & $2.19, \mathrm{~m} ; 1.89, \mathrm{~m}$ & $2.13, \mathrm{~m} ; 1.87, \mathrm{~m}$ & $2.16, \mathrm{~m} ; 1.89, \mathrm{~m}$ \\
\hline 16 & $1.97, \mathrm{~m}$ & $2.48, \mathrm{~m}$ & $1.91, \mathrm{~m}$ & $1.88, \mathrm{~m}$ \\
\hline 17 & & 107 & & \\
\hline 18 & $0.95(\mathrm{~s})$ & $1.07(\mathrm{~s})$ & $0.99(\mathrm{~s})$ & $0.97(\mathrm{~s})$ \\
\hline 19 & $1.63(\mathrm{~s})$ & $1.68(\mathrm{~s})$ & $1.64(\mathrm{~s})$ & $1.48(\mathrm{~s})$ \\
\hline 20 & -------------- & '-------------' & -----------' & ---------------' \\
\hline 21 & $4.01 \mathrm{~d}, 4.03 \mathrm{~d}$ & $4.81 \mathrm{~d}, 4.98 \mathrm{~d}$ & $4.13(\mathrm{dd} 19.2,5.9)$ & $4.83(\mathrm{dd} 17.3)$ \\
\hline & $(16.7,16.7)$ & $(17.6,17.6)$ & $4.32(\mathrm{dd} 19.4,5.7)$ & $4.94(\mathrm{dd} 17.3)$ \\
\hline 22 & --------------- & -------------- & ------------- & --------------- \\
\hline 23 & $2.37(\mathrm{q} 7.5)$ & $2.49(\mathrm{dq} 1.7,7.6)$ & ------------ & 2.49 (q 7.7) \\
\hline 24 & $1.15(\mathrm{t} 7.5)$ & $1.16(\mathrm{t} 7.6)$ & ------------ & $1.17(\mathrm{t} 7.7)$ \\
\hline $16 \beta \mathrm{CH} 3$ & $1.38(\mathrm{~d} 7.4)$ & $1.19(\mathrm{~d} 7.4)$ & $1.09(\mathrm{~d} 7.2)$ & $1.18(\mathrm{~d} 7.4)$ \\
\hline $11 \beta \mathrm{OH}$ & $2.4(\mathrm{~d} 3.7)$ & $1.4(\mathrm{~d} 2.6)$ & $5.35(\mathrm{~d} 4.7)$ & ----------- \\
\hline $17 \alpha \mathrm{OH}$ & ---------- & -------------- & $5.45(\mathrm{~s})$ & $1.9(\mathrm{~s})$ \\
\hline $21 \mathrm{OH}$ & --------- & -------------- & $4.6(\mathrm{t} 5.6)$ & --------- \\
\hline
\end{tabular}

NOTE: Assignments based on COSY, HMBC, and HMQC spectra. Assignments shown without multiplicity and multiplet.

that the compound has unsaturated carbonyl system. The ${ }^{13} \mathrm{C}$ - and ${ }^{1} \mathrm{H}-\mathrm{NMR}$ spectra showed the presence of the double bond between $\mathrm{C}-1 / \mathrm{C}-2$ and $\mathrm{C}-4 / \mathrm{C}-5$. The ${ }^{1} \mathrm{H}-$ and ${ }^{13} \mathrm{C}$-NMR data for metabolite (4) is given in Tables I and II, respectively. The ${ }^{13} \mathrm{C}-\mathrm{NMR}$ spectrum $\left(100 \mathrm{MHz}, \mathrm{CDCl}_{3}\right)$ (including BB, dept 90, and dept135) of (4) showed the resonances for 3 methyl, 5 methylene, 7 methine, and 7 quaternary carbons. At position $17 \alpha$, a hydroxyl group is present, and at position 21, a hydroxyl group is again present.

Mass spectra indicated that the mass of this compound is $409.1 \mathrm{Da}$, which is 111.94 mass units less than the substrate (521.04) and also showed the removal of $\mathrm{COC}_{2} \mathrm{H}_{4}$ (56 mass units) and again $\mathrm{COC}_{2} \mathrm{H}_{4}$ (56 mass unit). The net 112 mass units are less than the substrate. So metabolite (4) was thus identified as beclomethasone (BOH).

Compound (5) had an elemental composition $\mathrm{C}_{25} \mathrm{H}_{32} \mathrm{O}_{6}$, deduced through HREI-MS ( $\mathrm{M}+=\mathrm{m} / \mathrm{z} 429.5$ ), and molecular weight is $431 \mathrm{~g} / \mathrm{mol}$. The compound showed fluorescence beneath the UV light. This suggested that the compound has unsaturated carbonyl system. The ${ }^{13} \mathrm{C}$ - and ${ }^{1} \mathrm{H}-\mathrm{NMR}$ spectra showed the presence of the double bond between $\mathrm{C}-1 / \mathrm{C}-2$ and $\mathrm{C}-4 / \mathrm{C}-5$. The ${ }^{1} \mathrm{H}-$ and ${ }^{13} \mathrm{C}-\mathrm{NMR}$ data for metabolite (5) is given in Tables I and II, respectively. The ${ }_{13} \mathrm{C}$-NMR spectrum $\left(100 \mathrm{MHz}, \mathrm{CDCl}_{3}\right.$ ) (including $\mathrm{BB}$, dept 90, and dept135) of (5) showed the resonances for 4 methyl, 6 methylene, 7 methine, and 8 quaternary carbons. Also at position 21, methyl and methylene group are present, and at position 17, $\alpha$ hydroxyl group is present. $11 \beta \mathrm{OH}$ is also removed, and no spectral data for 17 $\mathrm{COC}_{2} \mathrm{H}_{5}$ at position carbon 17 instead of $17 \alpha$-hydroxyl group is present. At position of carbon 11, the resonance of $\mathrm{CH}$ is present instead of $\mathrm{CH}_{2}$ and provides the data of oxygen atom, which also gives resonance with carbon 9 position. Its mean chlorine atom is removed, and epoxy bond is produced between carbon 9 and 11 positions. 
TABLE II - ${ }^{13} \mathrm{C}-\mathrm{NMR}\left(100 \mathrm{MHz}, \mathrm{CDCl}_{3}\right)$ data of compounds $(2,3,4$, and 5)

\begin{tabular}{|c|c|c|c|c|}
\hline Carbon no & $\begin{array}{c}\text { Compound (2) } \\
\delta_{\mathrm{C}} \\
\end{array}$ & $\begin{array}{c}\text { Compound (3) } \\
\delta_{\mathrm{C}} \\
\end{array}$ & $\begin{array}{c}\text { Compound (4) } \\
\delta_{\mathrm{C}} \\
\end{array}$ & $\begin{array}{c}\text { Compound (5) } \\
\delta_{\mathrm{C}} \\
\end{array}$ \\
\hline 1 & 148.9 & 149.5 & 149.6 & 153.5 \\
\hline 2 & 127.2 & 128.2 & 128.4 & 128.9 \\
\hline 3 & 185.3 & 185.8 & 185.6 & 185.8 \\
\hline 4 & 125.1 & 124.3 & 124.4 & 124.9 \\
\hline 5 & 168.5 & 168.2 & 168.3 & 166.4 \\
\hline 6 & 32.7 & 32.7 & 32.3 & 29.8 \\
\hline 7 & 28.9 & 29.2 & 29.2 & 31.6 \\
\hline 8 & 36.9 & 38.3 & 38.1 & 34.6 \\
\hline 9 & 72.9 & 73.2 & 73.5 & 69.3 \\
\hline 10 & 63.4 & 62.7 & 62.8 & 44.8 \\
\hline 11 & 70.1 & 70.1 & 70.2 & 64.4 \\
\hline 12 & 34.8 & 35.3 & 35.1 & 33.8 \\
\hline 13 & 46.7 & 47.3 & 47.1 & 49.6 \\
\hline 14 & 43.1 & 42.2 & 42.6 & 47.2 \\
\hline 15 & 32.7 & 32.2 & 32.4 & 32.4 \\
\hline 16 & 46.7 & 36.3 & 38.4 & 38.9 \\
\hline 17 & 94.1 & 92.2 & 92.5 & 91.3 \\
\hline 18 & 17.5 & 17.1 & 17.3 & 16.9 \\
\hline 19 & 27.7 & 28.2 & 28.3 & 23.9 \\
\hline 20 & 204.5 & 211.3 & 211.4 & 205.4 \\
\hline 21 & 67.1 & 66.4 & 66.5 & 68.7 \\
\hline 22 & 173.5 & 173.4 & -------- & 172.9 \\
\hline 23 & 27.7 & 27.5 & -------- & 28.5 \\
\hline 24 & 10.1 & 9.5 & -------- & 10.6 \\
\hline
\end{tabular}

Mass spectra indicated that the mass of this compound is $429.5 \mathrm{Da}$, which is 91.54 mass units less than the substrate (521.04 and also showed the removal of $\mathrm{COC} 2 \mathrm{H} 4$ (56 mass units) and chlorine atom (35.5 mass unit). The net 91.5 mass units are less than the substrate. So metabolite (5) was thus identified as 9beta, 11 beta-epoxy-17, 21-dihydroxy-16beta-methylpregna-1, 4-diene-3, 20-dione 21-propionate.

\section{DISCUSSION}

The potential route of synthesis of these compounds is as follows. Compound (5) has only been reported chemically by Van Leusen in 1994. In this approach, the starting material was 21-acetoxy-4, 9 (11), 16-pregnatriene-3, 20 -dione, leading to four-stepped chemical reaction requiring a variety of chemicals and conditions resulting in the formation of the epoxy derivative, whereas in biotransformation, a number of reactions can be accomplished in one container, and reactions under mild conditions was required even at room temperature. As there was no hazardous substances used for the production of these metabolites so it could be denominated as green chemistry while chemical synthesis involved hazardous chemicals lead to the environmental pollution. Aspergillus niger had an ability to hydrolyze the compounds because of the presence of hydrolase enzymes in its enzyme system (El-Refai et al., 2012). Two reactions were involved in the synthesis: ester hydrolysis and loss of $\mathrm{HCl}$ to form an epoxide shown in Figure 1. Compounds (2, 3, and 4) were reported only by human metabolism (Foe et al., 1997). The four compounds produced were two monopropionates, that is, beclomethasone 17-monopropionate (2) and beclomethasone 21-monopropionate (3), one epoxy (5), and one depropionated derivative (4). Compound (4) was already reported as pharmacologically inactive, and compound (2) was pharmacologically active (Nave, Fisher, McCracken, 2007), whereas compound (3) was reported as pharmacologically inactive compound (Würthwein, Rohdewald, 1990). It is expected that the new metabolites formed may have more anti-inflammatory activity; better therapeutic profile, safety, and efficacy; and least resistance and can be employed in the treatment of asthma as that of the parent compound.

In the present study, we could produce these compounds outside the body, which showed the definite 
potential of the emerging route of metabolism of drug as well as new drug discovery from the existing one.

\section{CONCLUSION}

Microbial biotransformation of beclomethasone dipropionate by Aspergillus niger resulted in four metabolites produced first time from microbial biotransformation, which showed the potential of this route as a model to the study of the metabolism of beclomethasone dipropionate in mammalian and also illustrated the enzymatic potential of Aspergillus niger. The four compounds included two monopropionates, one epoxy, and one depropionated derivative. Depropionated metabolite was already reported as pharmacologically inactive, whereas beclomethasone 17-monopropionated was pharmacologically active, and beclomethasone 21-monopropionated was pharmacologically active. It is expected that the epoxide derivative may have more antiinflammatory activity than the parent compound.

\section{ACKNOWLEDGMENTS}

We acknowledge the H.E.J., Research Institute of Chemistry, University of Karachi, Karachi, Pakistan, for the technical support in elucidating the structures of compound using modern techniques of NMR spectroscopy.

\section{REFERENCES}

ABOURASHED, E.A.; CLARK, A.M.; HUFFORD, C.D. Microbial models of mammalian metabolism of xenobiotics: an updated review. Curr. Med. Chem., v.6, p.359-374, 1999.

AL-ABOUDI, A.; MOHAMMAD, M.Y.; HADDAD, S.; ALFAR, R.; CHOUDHARY, M.I.; ATTA-UR-RAHMAN. Biotransformation of methyl cholate by Aspergillus niger. Steroids, v.74, p.483-486, 2009.

AUBIER, M.; SASTRE, J.; IZQUIERDO, J.L.; ADLER, L.M.; HOFBAUER, P.; ROST, K.D.; HARNEST, U.; KROEMER, B.; BREDENBRÖKER, D.; ALBRECHT, A. Comparison of roflumilast, an oral anti-inflammatory, with beclomethasone dipropionate in the treatment of persistent asthma squet. Allergy, v.61, p.72-78, 2006.

CHERVINSKY, P. Clinical review of once-daily beclomethasone dipropionate for seasonal allergic rhinitis. Clin. Ther., v.18, p.790-796, 1996.
CHOUDHARY, M.I.; ERUM, S.; ATIF, M.; MALIK, R.; KHAN, N.T.; ATTA-UR-RAHMAN. Biotransformation of (20S)-20-hydroxymethylpregna-1,4-dien-3-one by four filamentous fungi. Steroids, v.76, p.1288-1296, 2011.

CHOUDHARY, M.I.; KHAN, N.T.; MUSHARRAF, S.G.; ANJUM, S.; ATTA-UR-RAHMAN. Biotransformation of adrenosterone by filamentous fungus. Cunninghamella elegans. Steroids,v.72, p.923-929, 2007.

CHOUDHARY, M.I.; MOHAMMAD, M.Y.; MUSHARRAF, S.G.; PARVEZ, M.; AL-ABOUDI, A.; ATTA-URRAHMAN. New oxandrolone derivatives by biotransformation using Rhizopus stolonifer. Steroids, v.74, p.1040-1044, 2009.

CHOUDHARY, M.I.; SHAH, S.A.A.; ATTA-UR-RAHMAN; KHAN, S.N.; KHAN, M.T.H. $\alpha$-Glucosidase and tyrosinase inhibitors from fungal hydroxylation of tibolone and hydroxytibolones. Steroids, v.75, p.956-966, 2010.

CHOUDHARY, M.I.; ZAFAR, S.; KHAN, N.T.; AHMAD, S.; NOREEN, S.; MARASINI, B.P.; AL-KHEDHAIRY, A.A.; ATTA-UR-RAHMAN. Biotransformation of dehydroepiandrosterone with Macrophominaphaseolina and $\beta$-glucuronidase inhibitory activity of transformed products. J. Enzyme. Inhib. Med. Chem.,v.27, p.348-355, 2012.

DONOVA, M.V.; EGOROVA, O.V. Microbial steroid transformations: current state and prospects. Appl. Microbiol. Biotechnol., v.94, p.1423-1447, 2012.

DEVKOTA, K.P.; CHOUDHARY, M.I.; NAWAZ, S.A.; LANNANG, A.M.; LENTA, B.N.; FOKOU, P.A.; SEWALD, N. Microbial transformation of the steroidal alkaloid dictyophlebine by Rhizopusstolonifer. Chem. Pharm. Bull., v.55, p.682-684, 2007.

EL-REFAI, A.H.; SALLAM, L.A.R.; EL-MENOUFY, H.A.; AMIN, H.A.S. Physiological and chemical studies on the bioconversion of glycyrrhizin by Aspergillus niger. Mal. J. Microbiol., v.8, p.75-82, 2012.

FASCÌ, S.F.; ARATARI, A.; MARGAGNONI, G.; DODDATO, M.T.; CHIESARA, F.; PAPI, C. Oral beclomethasone dipropionate: a critical review of its use in the management of ulcerative colitis and Crohn's disease. Curr. Clin. Pharmacol., v.7, p.131-6, 2012. 
FOE, K.; CHEUNG, H.T.A.; TATTAM, B.N.; BROWN, K.F.; SEALE, J.P. Degradation products of beclomethasone dipropionate in human plasma. Drug Metab. Dispos., v.26, p.132-137, 1997.

FOUAD, W.A.; ABBAS, I.H.; ELWAN, K.M.; SWELLUM, M.A.; EL-DOUGDOUG, K. A biotransformation of progesterone by microbial steroids. J. Appl. Sci. Res., v.5, n.1, p.137-143, 2009.

KANAZAWA, H.; NOMURA, S.; HIRATA, K.; YOSHIKAWA, JUNICHI. Effect of inhaled beclomethasone dipropionate on peroxynitrite inhibitory activity in induced sputum from asthmatic patients. Chest, v.124, p.1755-1761, 2003.

NAVARATNAM, P.; EDUARDO, R.; URDANETA; MCLAUGHLIN, J.; HOWARD, S.; FRIEDMAN. Comparative effectiveness of mometasone furoate inhalation powder versus beclomethasone dipropionate hydrofluoroalkane aerosol in the treatment of controllernaive patients with mild, persistent asthma free to view. Chest, v.136, n.4, p.85-95, 2009.

NAVE, R.; FISHER, R.: MCCRACKEN, N. In vitro metabolism of beclomethasone dipropionate, budesonide, ciclesonide, and fluticasone propionate in human lung precision-cut tissue slices. Respiratory Res., v.8, p.65, 2007.
SEPURI, A.; MARAVAJHALA, V. Cunninghamella: a microbial model for drug metabolism studies: a review. Biotechnol. Adv.,v.27, p.16-29, 2009.

TONG, W.Y.; DONG, X. Microbial biotransformation: recent development on steroid drugs. Recent Pat. Biotechnol., v.3, p.141-153, 2009.

VAN LEUSEN, D.; VAN LEUSEN, A.M. Synthesis of triamcinolone acetonide from 9-hydroxy-3-methoxy-17(2-methoxy-3-oxazolin-4-yl)androsta-3,5,16-triene. J. Org. Chem., v.59, p.7534-7538, 1994.

WÜRTHWEIN, G.; ROHDEWALD, P. Activation of beclomethasone dipropionate by hydrolysis to beclomethasone-17-monopropionate. Biopharm. Drug Dispos., v.11, n.5, p.381-394, 1990.

ZAFAR, S.; YOUSUF, S.; KAYANI, H.A.; SAIFULLAH, S.; KHAN, S.; AL-MAJID, A.M.; CHOUDHARY, M.I. Biotransformation of oral contraceptive ethynodiol diacetate with microbial and plant cell cultures. Chem. Cent. J., v.6, p.109, 2012.

Received for publication on $20^{\text {th }}$ June 2013 Accepted for publication on $16^{\text {th }}$ December 2013 
